is a systemic challenge that has to be situated in a wider SSR context. International police officers will of course be necessary, but most likely in smaller numbers. In addition, a range of diverse skills and resources is needed for a sustained period of time to effectively support post-conflict police development. ${ }^{50}$ Such experts, together with international police officers, should be integrated in multi-dimensional peace operations and crisis management missions, and organised around clearly defined objectives of police development within a framework

50 Already in 2000, the UN Panel on Peace Operations called for a "doctrinal shift in the use of civilian police and related rule of law elements in peace operations that emphasizes a team approach to upholding the rule of law and respect for human rights and helping communities coming out of a conflict to achieve national reconciliation (emphasis added) (United Nations, Report of the United Nations Panel on Peace Operations, UN Doc. A/55/305-S/2000/809 (21 August 2000), ix). This change in approach would probably also help to bring down the overall number of international mission personnel and reduce mission costs. Already, international police officers are not available in sufficient numbers. of SSR. ${ }^{51}$ Post-conflict police development is too important, and supporting it is too costly, to not learn lessons from past efforts.

51 See also United Nations Department of Peacekeeping Operations and Department of Field Support, A New Partnership Agenda. Charting a New Horizon for UN Peacekeeping (New York: United Nations, 2009) that calls for mission mandates with clearly achievable objectives. An alternative to mandating multi-dimensional peacekeeping operations and crisis management missions with police development would be to restrict their mandates to core policing tasks and to provide other support by means of voluntary bilateral or multilateral assistance. The unevenness and haphazardness of such assistance represents, however, a significant risk.

\title{
Wearing the Outside In: Internal Deployment of the Armed Forces in Germany and Italy
}

\section{Derek Lutterbeck*}

\begin{abstract}
Since the end of the Cold War, many if not all, European or Western countries have increasingly used their armed forces for missions within the borders of the state. The aim of this article is to compare the internal deployment of the military in two European countries: Germany and Italy, both of which experienced authoritarian rule and militarism in the 20th century. However, despite similar historical experiences, there have been considerable differences between the two countries in terms of the roles their armed forces have come to play in addressing domestic challenges in recent years. Indeed, they may represent opposite extremes on a spectrum ranging from very limited to very far-reaching involvement of military forces in internal (security) matters.
\end{abstract}

Keywords: External security, internal security, military, police, Germany, Italy

Äußere Sicherheit, Innere Sicherheit, Militär, Polizei, Deutschland, Italien

\section{Introduction}

$\mathrm{T}$ The distinction between internal and external security, and between police and military functions, traditionally considered a core principle of the liberal-democratic state, has become increasingly blurred. This development has been manifest in a number of ways, such as the growing internationalization of policing, or the convergence between law enforcement and foreign intelligence, but the most visible-and arguably also the most problematic-aspect of the convergence between internal and external security functions has been the increasing use of military forces within

Dr. Derek Lutterbeck is Deputy Director and Holder of the Swiss Chair at the Mediterranean Academy of Diplomatic Studies, Malta. The author would like to thank Anna Khakee and the anonymous reviewers for most helpful comments on earlier versions of this article. - Peer-reviewed article. the boundaries of the state. ${ }^{1}$ While often associated with authoritarian regimes and repressive practices, in recent years, many if not all, liberal-democratic states have increasingly used their armed forces on national territory. Somewhat surprisingly though, this development has thus far not received much attention in academic literature. Whereas a number of studies exist on the changing role of military force in the post-Cold War era, the focus has almost exclusively been on the new tasks and functions military forces have come to assume in the context of international peace operations. The growing involvement of

1 For a general discussion of the merger of internal and external security in the European context, see e.g. Didier Bigo, 'When two become one: internal and external securitisations in Europe', in Morten Kelstrup, Michael C. Williams, eds, International Relations Theory and the Politics of European Integration, Power, Security and Community (London: Routledge, 2000), 171-205; Derek Lutterbeck, 'Blurring the Dividing Line: The Convergence of Internal and External Security in Western Europe', European Security, Vol. 14, No. 2 (June 2005), 231-253. 
militaries in addressing domestic challenges, by contrast, has thus far been largely neglected. ${ }^{2}$

The aim of this article is to discuss and compare internal deployments of the military in two European countries: Germany and Italy. Authoritarianism and militarism marked the history of both of these countries in the 20th century when the Nazi and Fascist dictatorships used military or paramilitary forces to suppress dissent and fight alleged "enemies" of the state internally. In the post-Cold War period, in both Germany and Italy the use of the military for domestic purposes has again been on the agenda. However, despite similar historical experiences, there have been considerable differences between the two countries in terms of the role their armed forces have come to play in internal matters. Indeed, they may represent opposite extremes on a spectrum ranging from very limited to very far-reaching domestic involvement of military forces. The article also points to a number of factors which could explain the differences between the internal roles the armed forces have assumed in the two countries, and reflects on the extent to which these developments signal a move towards more authoritarian or militarized domestic security practices.

\section{Germany: Mainly logistical support functions}

In comparison to other European countries, the use of the armed forces in Germany for internal purposes has for historical reasons been subject to (much) stricter preconditions. According to the German Constitution, or "Basic Law" (Grundgesetz), the task of the Bundeswehr is explicitly restricted to defending the country against military attacks, and it may only be used for other purposes if explicitly mentioned in the Basic Law. ${ }^{3}$ Until the 1960s, the only instance in which the armed forces could be deployed on national territory was in the event of natural or man-made disasters. ${ }^{4}$ In 1968, however, in response to growing internal unrest, the so-called emergency legislation (Notstandsgesetzgebung) was adopted, which somewhat widened the Bundeswehr's internal functions, but also set rather clear limits. In addition to natural or man-made catastrophes, the armed forces may, according to the amended (and current) Constitution also be deployed on national territory to counter an "impending threat to the liberal-democratic order". In both cases, however, according to the Basic Law, the Bundeswehr may be used only for the following tasks: to protect civilian property, to perform traffic control functions, and to fight organized and militarily armed insurgents. ${ }^{5}$

According to the Basic Law, the internal role of the Bundeswehr is thus confined not only to certain situations (although these might leave considerable room for interpretation) but

2 The only existing recent account of this development, focusing mainly on Anglo-Saxon countries, seems to be: Michael Head and Scott Mann, Domestic Deployment of the Armed Forces. Military Powers, Law and Human Rights (Surrey: Ashgate, 2009).

3 Article $87 \mathrm{a}(2)$ of the Basic Law.

4 Article 35 of the Basic Law.

5 Article 87a (3) and (4) of the Basic Law. In addition, it is commonly agreed that the armed forces may perform tasks which are below the level of an actual military "deployment" (Einsatzschwelle) such as purely humanitarian, caritative or social activities. See, e.g., Willhelm Knelangen and Jan Irlenkaueser, 'Die Debatte über den Einsatz der Bundeswehr im Innern, Kieler Analysen zur Sicherheitspolitik, Nr.12, March 2004. also to specifically and rather narrowly defined tasks. In the 1960s, some leaders of the centre-right Christian Democratic Union (CDU) had called for a stronger internal role of the Bundeswehr in particular in areas such as strike or riot control. Such provisions could not be introduced, however, as they were opposed by the Social Democratic Party (SPD) and thus failed to achieve the two-thirds parliamentary majority necessary for a constitutional amendment. ${ }^{6}$

Nevertheless, despite the above-mentioned constitutional limitations, the German armed forces have been used for a growing number of operations on national territory. These missions seem to have been on the rise in particular since the early 1990s. While there is no complete account of all internal deployments of the Bundeswehr, in 2007 in response to a parliamentary request from The Left party (Die Linke), the German government provided a very detailed inventory of all domestic missions that had taken place since 1997. According to this overview a total of 352 internal operations were carried out between 1997 and 2007. These have varied greatly in size, ranging anywhere from the deployment of a single soldier to more than 40,000 troops. ${ }^{7}$ Overall, these missions have been considered to be within the above-mentioned constitutional restrictions, at least by Germany's main political forces, although some of them have also met with severe criticism from the left of the political spectrum. They have generally been confined to logistical or technical support activities, and have, according to the German government, not involved the exercise of any executive powers by the armed forces. ${ }^{8}$

The least controversial operations have been the Bundeswehr's support missions in the event of natural or man-made disasters. Between 1997 and 2007, the German armed forces were used for 71 missions of this kind, the most significant of which took place during and after natural disasters, most often floods. ${ }^{9}$ One of the largest operations thus far took place in 2002, when the Donau and Elbe rivers burst their banks and some 45,000 soldiers, as well as aircraft and other military equipment, were deployed to give assistance to the population and the civilian authorities in the affected areas.

The second type of internal deployments have involved support activities to the civilian authorities in the event of particularly dangerous police operations, such as transport of nuclear materials, or large public events, such as summits or major sporting events. Between 1997 and 2007, 61 operations of this type took place. These deployments were usually much smaller than the disaster support operations, involving on average 30-40 soldiers. ${ }^{10}$ During these missions, troops have typically provided logistical, material or technical support to the police and other civilian authorities. The largest such operation thus far was the deployment of around 2,000 soldiers during the soccer World Cup in 2006. The main tasks of the Bundeswehr

6 Stefan Gose, 'Bundeswehr im Innern', Zeitschrift Bürgerrechte \& Polizei/CILIP, 70 (2001), pp. 49-54

7 Deutscher Bundestag, Drucksache 16/6159, 16. Election Period, 26 July 2007.

8 Ibid.

9 On average, they inolved around 1,500 soldiers (calculated on the basis of Deutscher Bundestag, op.cit., annex 2).

10 Calculated on the basis of Deutscher Bundestag, op.cit., annex 1. 
during this event consisted in the provision of medical services, logistical support as well as air surveillance. ${ }^{11}$

Finally, the armed forces have been used for rather small-scale missions in favor of third parties (Leistung gegenüber Dritten), a type of operation not explicitly regulated in the Constitution. For the most part, these have been relatively minor deployments of around 20-30 soldiers on the occasion of various types of public gatherings, such as Christmas fairs or conferences. While these missions have been the smallest in size, they have been the largest in number: between 1997 and 2007, the German armed forces were mobilized 210 times for such occasions. The most important of these deployments took place at the annual Munich Security Conference, where in recent years around 400 soldiers have provided logistical support during the event.

As pointed out previously, the above-mentioned operations have overall been relatively uncontroversial among Germany's mainstream political parties, yet since the beginning of 1990s, there have been (renewed) calls for giving the Bundeswehr a more prominent internal role. As in the 1960s, initiatives in this direction have come mainly from the CDU, which has been the principal advocate of stronger involvement of the German armed forces not only internationally in out-of-area operations but also on the national territory. ${ }^{12}$ Initially, in the early 1990s, the main area where at least some CDU exponents called for a more important internal role for the Bundeswehr was the one of border and immigration control, although the issue of international terrorism also figured in the debate. In 1993, for example, when Germany was confronted with a sharp rise in irregular migration across the country's eastern frontiers, Wolfgang Schäuble, at the time head of the CDU faction in the German parliament, as well as some other CDU leaders, called for the deployment of the Bundeswehr along the borders to prevent irregular immigration. Schäuble argued that, given the emergence of new security challenges such as migration and terrorism, the distinction between internal and external security had become increasingly obsolete:

In an age of global migratory flows and international terrorism, the distinction between internal and external security is increasingly difficult to maintain. Therefore, we should reflect upon whether the Bundeswehr should not, under strictly defined conditions, be deployed internally, as is the case for the armed forces of all other civilized countries. ${ }^{13}$

Schäuble's initiative, however, met with considerable criticism, not only from the Social Democrats (who were in opposition at the time) but also from within his own party. Then-Minister of Defense, Volker Rühe from the CDU, opposed the proposal, stating that "also in the future the distinction between internal and external security, and between police and army, has to be maintained". ${ }^{14}$ Similarly, then-foreign minister Klaus Kinkel

11 Frankfurter Allgemeine Zeitung, 9 February 2006.

12 The connection between the Bundeswehr's external and internal roles was emphasised , for example, by current Chancellor Angela Merkel at the Munich Security Conference of 2005, when she argued that the Bundeswehr's participation in international peace operations and in missions on the national territory were "two sides of the same coin" (Rede auf der XLI. Münchner Konferenz für Sicherheitspolitik, 12 February 2005, http://80.86.3.56/archive/ konferenzen/rede.php?menu_2005=\&menu_konferenzen=\&sprache=de\&id $=145 \&$.

13 Frankfurter Allgemeine Zeitung, 22 December 1993 (translation by author).

14 Berliner Morgenpost, 24 December 1993. from the Free Democratic Party (FDP) emphasized that the function of the Bundeswehr was restricted to "defending the country against the exterior", and that internal tasks generally fell under the responsibility of the police. ${ }^{15}$ Schäuble's proposal was subsequently rejected by a clear majority in the German parliament. ${ }^{16}$

The terrorist attacks on the US on 11 September 2001 gave renewed impetus to the debate on the potential internal role of the Bundeswehr, which now came to focus almost exclusively on the (perceived) threat of international terrorism. In the immediate aftermath of 9/11, a number of leading CDU politicians called for a constitutional amendment which would allow the German armed forces to be deployed within the country to fight terrorism. They argued that, given the "increasing brutality of terrorist attacks", only the Bundeswehr had the necessary means and know-how to counter this threat. ${ }^{17}$ As earlier, however, these demands were rejected by the SPD, which at the time was in coalition government with the Green Party. Both parties considered it unacceptable that the internal role of the armed forces would go beyond the existing legal regulations. ${ }^{18}$

During the 2002 national elections, the issue figured prominently in the debate. One of the main items on CDU Chancellor Candidate Edmund Stoiber's agenda in the area of security and defence policy was to give the Bundeswehr a more important domestic role, for example in protecting airports or nuclear installations against terrorist attacks. ${ }^{19}$ As these elections were (narrowly) won by the SPD and the Greens, no such changes were introduced, however. Nevertheless, the ruling red-green coalition took a step - albeit a modest one - towards giving the German armed forces more powers in the area of counter-terrorism: it amended the Aviation Security Act (Luftsicherheitsgesetz) so as to allow fighter aircraft to shoot down hijacked passenger planes in cases when they were to be used to commit terrorist acts. The amendment, however, was subsequently struck down by the German Constitutional Court, as it was considered incompatible with the Basic Law and in particular with the right to life enshrined therein. The Constitutional Court also ruled that the Act unconstitutionally expanded the Bundeswehr's domestic powers. ${ }^{20}$

When a grand coalition between the CDU and the SPD took power in 2005, the question of the domestic deployment of the Bundeswehr was, once again, one of the most contentious issues between the two coalition partners in the field of security and defence policy. The traditional CDU position was to some extent reflected in the coalition agreement which the two parties signed in late 2005: in the agreement, it is stated that in view of "asymmetric threats" and in particular terrorism, the "distinction between internal and external security could no longer be neatly drawn." As a consequence, "the Government will put forward proposals to amend the constitution as well as other legislation, if the country's security situation should

15 Berliner Zeitung, 31.12.1993; Berliner Morgenpost, 3 January 1994.

16 Berliner Zeitung 15.1.1994; Tageszeitung, 15 January 1994.

17 Die Welt, 29 November 2001.

18 Handelsblatt, 16 June 2002.

19 Die Welt, 17 June 2002.

20 Bundesverfassungsgericht, Press Release Nr. 11/2006, 15 February 2006. 
require such a measure" ${ }^{21}$ Initially the SPD seemed to be willing to discuss the issue, thus marking a significant shift from its traditional position, however it subsequently backtracked. SPD leaders refused to introduce any amendments to the Basic Law which would have widened the Bundeswehr's internal role, arguing that this would amount to "an unacceptable qualitative change in [Germany's] security architecture”. ${ }^{22}$

Nevertheless in 2006, as previously mentioned, the SPD coalition government agreed to deploy the armed forces during the soccer World Cup, which with the exception of its disaster assistance missions discussed above, has been the Bundeswehr's largest domestic operation to date. The nature of the operation was, however, the result of a compromise between the two coalition partners. While the CDU, and in particular Interior Minister Schäuble, wanted a stronger role for the armed forces during the World Cup, which would have also included police-type activities such as protection of sensitive objects and identity checks, the SPD would only agree that the Bundeswehr perform logistical and medical support functions. ${ }^{23}$

Even though no constitutional changes have thus far been made which would allow the German armed forces to play a more significant domestic role in fighting terrorism and other similar challenges on the national territory, several recent key documents on Germany's security and defence policy nevertheless seem to point in this direction. Thus, in Germany's most recent Guidelines on Defence Policy (Verteidigungspolitische Richtlinien), for example, protecting the population and vital infrastructure against terrorist attacks and other "asymmetric threats" is mentioned as one of the Bundeswehr's main tasks. While the document states that the primary responsibility in this area lies with the country's internal security forces, it also declares that the military will be deployed "within the framework of the existing legal order" in cases when "effective protection of the citizens and vital infrastructure ... can only be ensured by the armed forces". ${ }^{24}$ The German government has underlined that the defence policy guidelines do not widen the Bundeswehr's domestic role beyond current constitutional provisions, but some left-wing policy-makers have argued that these provisions are incompatible with the restrictions on the internal use of the military contained in the Basic Law. ${ }^{25}$

While on the political level, resistance against granting the armed forces a stronger domestic role has come mainly from the SPD (as well as parties further to the left), among the country's security institutions, it is the police that has been fiercely opposed to such measures. The proposals of some CDU leaders in the 1990s to assign the Bundeswehr a border control function, for example, were severely criticised by the German Federal Border Police as an infringement on its sphere of responsibility,

21 Gemeinsam für Deutschland. Mit Mut und Menschlichkeit. Koalitionsvertrag von CDU, CSU und SPD, 11 November.2005, p. 155 (translation by author). 22 Der Spiegel, 14 October 2008.

23 Frankfurter Allgemeine Zeitung, 9 February 2006.

24 Bundesministerium der Verteidigung, Verteidigungspolitische Richtlinien (Berlin: Bundesministerium der Verteidigung, 2003), p. 29 (translation by author). Similar provisions can also be found in the most recent White book on German security Policy, which was adopted in 2006, see Bundesministerium der Verteidigung, Weißbuch 2006 zur Sicherheitspolitik Deutschlands und zur Zukunft der Bundeswehr, Berlin, 2006, pp. 64-65.

25 Bundesausschuss Friedensratschlag, press release, 21 May 2003, available at: http://www.uni-kassel.de/fb5/frieden/themen/Bundeswehr/vpr-baf.html . and as amounting to an unacceptable "militarization" of the border. ${ }^{26}$ Similarly, police representatives also strongly opposed the decision of the German government to deploy the armed forces during the soccer World Cup, arguing that soldiers lacked the necessary training to deal with such an event. ${ }^{27}$

The attitude of the military leadership, for its part, has been more ambiguous. It seems clear that the disaster assistance missions described above have been welcomed by the Bundeswehr, most likely because they are considered to enhance its reputation among the population. ${ }^{28}$ When it comes to the armed forces' other internal missions, and in particular the question of the Bundeswehr's potential role in fighting terrorism and similar challenges on national territory, the military leadership has been very cautious in its comments and has mainly called for a clarification of the legal situation. While not as fiercely opposed as their police counterparts, representatives of the Germany's main military union, the German Armed Forces Association (Deutscher Bundeswehrverband), for example, have also expressed scepticism about involving the military in domestic security issues, pointing to the fundamentally different nature of police and military tasks. ${ }^{29}$ The decision to deploy the armed forces during the soccer World Cup, at least in the form originally envisaged by Interior Minister Schäuble, was also not welcomed by military representatives. Chairman of the Bundeswehr Association Bernhard Gertz, for example, criticised the decision, pointing out that "soldiers are not cheap auxiliary police" and that the training of the soldiers was not suitable for internal security missions. ${ }^{30}$

Finally, at the level of public opinion in Germany, there seems to be rather wide-spread support for using the armed forces for domestic purposes. According opinion polls from 2004 and 2006, a large majority of respondents declared themselves in favour of deploying the Bundeswehr on national territory, although the level of support depended on the aim of the mission. Disaster relief operations of the armed forces were viewed most favourably (87\%), whereas support was weakest for using the Bundeswehr for preventing irregular immigration $(60 \%){ }^{31}$

To summarise, in recent years, the German armed forces have been involved in a significant number of missions on the national territory, despite rather narrow constitutional constraints. There has also been a trend towards larger domestic operations, as evidenced in particular by the Bundeswehr deployments on the occasion of the soccer World Cup in

26 Gewerkschaft der Polizei, Bezirksgruppe BGS-Ost (1993) „Gewerkschaft der Polizei fordert: Keine Militarisierung der Grenze!“, press release, Franfurt a. O., 1 November 1993.

27 Deutsche Polizeigerwerkschaft Baden-Würtemberg, 'Verbandsinterner Informationsdienst, Nr.48, pp. 6-7.

28 It is noteworthy that the disaster relief missions are the only domestic operations which are mentioned on the website of the Bundeswehr. See http://www.bundeswehr.de/portal/a/bwde.

29 See, e.g., Deutscher Bundeswehrverband und Gewerkschaft der Polizei "Soldaten und Polizisten lehnen Vermischung des Schutzes von äußerer und innerer Sicherheit ab - Präzise Regelungen zur Amtshilfe gefordert", press release, 24 October 2006

30 Kölner Stadt-Anzeiger, 17 December 2005.

31 Thomas Bulmahn et al., Sicherheits- und verteidigungspolitisches Meinungsklima in der Bundesrepublik Deutschland. Ergebnisse der Bevölkerungsbefragung 2006 des Sozialwissenschaftlichen Instituts der Bundeswehr, Forschungsbericht 84 , Strausberg, April 2008. See also Wilhelm Knelangen and Jan Irlenkaueser, op. cit. 
2006 and those at the Munich Security Conference, where over the last ten years, the number of deployed troops has more than tripled. ${ }^{32}$ On the other hand, the German armed forces' tasks during these internal missions have thus far been largely confined to logistical and similar support functions. In particular, due to resistance from the SPD against amending the Basic Law and granting the Bundeswehr a stronger domestic role, the armed forces have thus far not been involved in actual policing or similar activities on national territory.

\section{Italy: Far-reaching military involvement in internal security}

In comparison to the German Bundeswehr, the Italian Armed Forces have been much more deeply involved in domestic security issues. Even though Italy during its fascist period also witnessed large-scale abuses of its armed forces for internal purposes, the country did not adopt the same kind of constitutional safeguards as Germany after the war with regards to the domestic deployment of the military. The Italian Constitution contains only one article on the armed forces which provides for their establishment and compulsory military service but it does not specify their tasks. ${ }^{33}$ The main law regulating the functions of the armed forces is the Military Service Act (Norme per l'istituzione del servizio militare professionale). The Act states that the primary duty of the military is to defend the state, but also provides for the internal deployment of the armed forces in rather broadly defined situations: in the event of "public calamities" and "cases of extraordinary need and urgency". ${ }^{34}$ Unlike the German Basic Law, however, the Act does not set any limits to the tasks the armed forces may assume when deployed in domestic missions.

In Italy, as in Germany, the internal use of the military seems to have been on the rise in particular since the beginning of the 1990s, even though the Italian armed forces were also involved in a number of important domestic missions from the end of World War II onwards. ${ }^{35}$ The official justification given by the Italian military for this "inward turn" is that the "classical enemy" has disappeared and has been replaced by a variety of new threats to the country's internal stability. To quote from the website of the Italian armed forces:

The classical image of the "enemy" has nowadays disappeared and been replaced by environmental disasters, massive and uncontrollable flows of immigrants and, not least, wide-spread and violent organized crime. This has led to the reorientation of the army from the defense of national sovereignty in the classical sense towards ensuring internal

32 In 1997, 115 soldiers were deployed during the conference; in 2007, the number was 410 (Drucksache 16/6159, 16. Election Period, 26 July 2007, annex 3).

33 Article 52 of the Constitution of the Italian Republic.

34 Article 1(5) of Law of 14 November 2000, no 331.

35 These have included, for example, operations to fight banditry in Sicily immediately after the end of WWII, counter-terrorist operations in South Tirol against separatist movements, or surveillance activities after the kidnapping of former President Aldo Moro. stability of the country through the deployment of army units to control the national territory. ${ }^{36}$

Officially, three types of domestic operations of the Italian armed forces are distinguished. ${ }^{37}$ First, similarly to the German Bundeswehr, the Italian military has been involved in disaster relief operations. As in Germany, this has involved mainly the provision of logistical and medical support during floods, earthquakes as well as other natural or man-made disasters. A mission of this kind took place in April 2009 in the central Italian town of Aquila, when around 1,500 soldiers, aircraft and other military equipment were deployed to provide assistance in the aftermath of the earthquake that shook the area. ${ }^{38}$

The second, and most significant, type of domestic deployment of the Italian armed forces has been those aimed at - $d$ in the official terminology - "safeguarding national institutions and public order" (salvaguardia delle libere istituzioni e per esigenze di ordine pubblico). These have been actual policing or law enforcement operations, mainly in areas such a crime and immigration control, during which the armed forces have supported - or acted in parallel to - the country's police forces. These deployments stand in stark contrast to the German example and are discussed in more detail below.

Finally, the Italian military has carried out operations on national territory in support of - to again use the official terminology - the "public interest" (pubblica utilità). Typically, these have been rather small-scale deployments for a broad variety of aims, such as ensuring public services in the event of strikes, disposal of unexploded ordinance, or demolition of unauthorized buildings. Probably the largest and most publicized mission of this kind was the so-called Operation Clean Streets (Operazione Strade Pulite), which was carried out in and around Naples in the summer of 2008. Around 500 soldiers were moved into the Campania region with the aim of tackling the "rubbish crisis", as waste disposal in the region had come to a halt and festering mountains of garbage were piling up in Naples and neighboring towns, posing a serious health risk to the population. ${ }^{39}$

Comparing domestic military deployments in Italy and Germany in purely numerical terms is difficult, as in Italy a comprehensive account of all internal missions has not been made public in the same way it has in Germany. However, the available information suggests that considerably more domestic deployments have taken place in Italy than in Germany: in 2008, for example, more than 2,500 operations of the third type alone were conducted in Italy, in addition to an unspecified number of missions under the other headings. ${ }^{40}$

An even more significant difference between Italy and Germany, however is that the Italian armed forces have been deployed in actual policing or law enforcement-type operations, as mentioned above. Between 1992 and 2008, eight missions of this kind were carried out in different parts of the country with

\footnotetext{
36 Esercito Italiano: Operazioni in patria, http://www.esercito.difesa.it/root/ attivita/op_index.asp (translation by author)

37 This categorisation is used in the annual reports (Rapporto Esercito) of the Italian Armed Forces.

38 Stato Maggiore della Difesa, communicato stampa, 17 April 2009.

39 Rapporto Esercito 2008 , p. 52.

40 Rapporto Esercito 2008, pp. 50-52
} 
some lasting for several years. The majority of these operations aimed at fighting organised crime and preventing irregular immigration, although counter-terrorism has also been a focus. During these policing missions, military forces have typically carried out activities such as forming road blocks, search and seizure operations and the protection of important public buildings. ${ }^{41}$ In most of these operations, the soldiers were also granted certain police-type powers - in the Italian legal terminology, they were assigned the status of so-called "agents of public security" (agente di pubblica sicurezza), according to which they have the authority to perform a number of policelike activities, such as to search, identify and detain persons. ${ }^{42}$

The longest and largest of the Italian armed forces' domestic policing missions to date took place in Sicily in the first half of the 1990s with the objective of fighting the Mafia - so-called Operation Vespri Siciliani. The operation was launched in response to the assassination of two anti-Mafia prosecutors and lasted from 1992 to 1998. It involved the deployment of between 2,500 and 6,000 soldiers at any one point in time whose main task was to support the police in its anti-Mafia operations, mainly in the form of (static) patrols and guarding duties. The operation was carried out under the responsibility of the civilian authorities, and the soldiers were assigned the above-mentioned police powers. The arrest of the Mafia leader Toto Rina one year after the operation was launched has been seen by the Italian military as one of the main successes of the mission. ${ }^{43}$

Apart from fighting organized crime, controlling irregular immigration has been another area where the armed forces have come to play an increasingly prominent internal role. The first anti-immigration operation by the Italian army was launched in 1993, when around 400 soldiers were stationed along the border to Slovenia in order to combat illegal immigration into Italy. ${ }^{44}$ Two years later, a second such mission took place, involving the deployment of a contingent of some 500 troops along the coast of Puglia to prevent migration from across the Adriatic. ${ }^{45}$ In the area of immigration control, the Italian navy has also been deeply involved. Since the first Albanian refugee crisis of 1991, the Italian navy has been active in preventing irregular immigration by sea towards Italy - despite the fact that the use of warships for this purpose, due to the potential risk it poses for sea-borne migrants, has met with widespread international criticism. Nowadays, immigration control is considered to be one of the Italian navy's most important fields of activity. 46

Subsequent to $9 / 11$, the Italian military was also deployed in a counter-terrorism operation on national territory. Shortly

41 For an overview, see Esercito Italiano: Operazioni in partria, http://www. esercito.difesa.it/root/attivita/op_index.asp.

42 A detailed description of the powers of "agents of public security" can be found in: Rapporto Esercito 2008, p. 56.

43 Esercito Italiano: Operazione Vespri Siciliani, http://www.esercito.difesa.it/ root/attivita/op_vespri.asp.

44 Esercito Italiano: Operazione Testuggine, http://www.esercito.difesa.it/root/ attivita/op_testuggine.asp.

45 Esercito Italiano: Operazione salento, http://www.esercito.difesa.it/root/ attivita/op_index.asp. See also La Stampa, 11 May 1995; Corriere della sera, 11 May 1995.

46 For a comprehensive discussion of this issue from the perspective of the Italian navy, see Fabio Caffio, L'Italia di fronte all'immigrazione clandestine via mare, Rome, 6 June 2005. after the terrorist attacks on the US, the Italian government launched so-called Operation Domino. Under this mission, troops of the Italian military were given the task of protecting NATO installations in Italy, as well as other important public facilities such as railway lines and airports, against potential terrorist attacks. ${ }^{47}$

The most recent, and in several ways the most significant, police-type mission of the Italian armed forces thus far has been so-called Operation Safe Streets (Operazione Strade Sicure) which was launched in August 2008. The operation was part of the "security package" adopted by the Berlusconi Government in mid-2008, which aimed at fighting crime in Italy. Under the framework of Operation Safe Streets, around 3,000 soldiers were deployed in a number of Italian cities in order to secure "sensitive objects" such as government buildings and embassies, and to carry out joint patrols with the police in the city centres. Moreover, the troops were tasked with guarding immigrant detention centres. As in Operation Vespri Siciliani, the soldiers were granted police-type powers, such as the right to search individuals and carry out temporary arrests of persons suspected of having committed criminal acts. ${ }^{48}$

Operation Safe Streets has marked the most far-reaching involvement of the Italian military in internal security matters to date in at least two ways. First, the operation has been given a very wide remit. According to the legislative decree on which the mission is based, the task of the troops is very broadly defined as preventing any behavior "which could put in danger the safety of persons or the security of the areas under surveillance". ${ }^{49}$ This seems to go significantly beyond the Italian armed forces' earlier domestic operations, which had a narrower focus on fighting the Mafia or immigration control. Second, even though the deployment has in some ways been comparable to the Vespri Siciliani operation of the 1990s, a notable difference is that the task of the armed forces has not been restricted to static protection of buildings and installations but also comprised mobile patrols to be carried out jointly with the police throughout the cities covered by the operation. One can thus speak of a further "police-ization" of the Italian military, or of a further militarization of internal security, in Operation Safe Streets.

Compared to the German Bundeswehr, the Italian armed forces have thus played a much more extensive role in internal security. This difference has also been reflected at the political level in that none of Italy's main political parties has been opposed as a matter of principle to the domestic deployment of the military in a policing function. Unlike the Social Democrats in Germany, Italian centre-left parties have not considered such a measure to be unacceptable. To be sure, the Berlusconi government's decision to launch Operation Safe Streets has met with rather severe criticism from the opposition parties, who have denounced it not only as an inadequate measure to fight crime but also as a "militarization of politics" and as part of a

\footnotetext{
47 Esercito Italiano: Operazione Domino, http://www.esercito.difesa.it/root/ attivita/op_Domino.asp.

48 Esercito Italiano: Operazione Strade Sicure, http://www.esercito.difesa.it/ root/attivita/op_stradesicure.asp, Rapporto Esercito 2008, p. 56.

49 Decreto Legge 90/2008, 23 March 2008 (translation by author).
} 
slide towards authoritarianism. ${ }^{50}$ On the other hand, it should be noted that the Italian military's thus far longest and largest domestic mission, Operation Vespri Siciliani, was initiated by a socialist-led government under the premiership of Giuliani Amato. Thus, it can hardly be argued that the Italian centreleft is not also willing to resort to such a policy if considered necessary. On a deeper level, this difference seems to be a reflection of different "strategic cultures" between the two countries, and in particular Germany's strong anti-militarism since the end of WWII, something which is briefly discussed below.

A similarity to the case of Germany, however, has been the considerable resistance to the growing domestic role of the Italian military coming from the country's (civilian) police forces. ${ }^{51}$ Both the anti-Mafia and the anti-immigration operations carried out during the first half of the 1990s were heavily criticized by representatives of the Italian police, who argued that these operations amounted to a "militarization of public order", and to an unacceptable blurring of police and military tasks. ${ }^{52}$ Operation Safe Streets also met with rather strong criticism from police representatives. The head of one of Italy's main police unions argued that deploying soldiers to fight crime was unacceptable in a liberal democratic state, and that instead of using the military to provide security in Italian cities, the police should be given more human and financial resources. ${ }^{53}$

The Italian military, for its part, and again somewhat in contrast to the German armed forces, seems to have welcomed its growing involvement in operations on the national territory. At least in official documents, the increasing number of domestic missions carried out is described as a (very) positive development. In the annual reports of the army, for example, it is seen as a sign of the armed forces' "extreme versatility" and as evidence of its increasing "closeness to the people". ${ }^{4}$

When it comes to public opinion, also in Italy the deployment of the military for internal purposes seems to be broadly supported by the population. According to the most recent opinion poll, which however is somewhat outdated (from 1997), almost $80 \%$ of respondents were in favour of deploying the armed forces on national territory to support the police and other public institutions. The case of Italy is noteworthy in that support for domestic use of the military was strongest for fighting organised crime; stronger even than for disaster support operations. ${ }^{55}$

50 See, e.g., La Repubblica, 14 June 2008.

51 In addition to civilian police forces at the national (Polizia di Stato) and local levels, Italy also has two police forces at the national level with military status: the Carabinieri which are formally part of the Italian Armed Forces, and the Guardia di Finanza which are at least partly controlled by the Ministry of Defence.

52 “Soldati antimafia", Ordine Pubblico, 1994/3, pp. 44-47. See also Il Giornale, 11 May 1995

53 La Repubblica, 30 July 2008; Il Tempo, 26 January 2009; Gazetta del Sud, 10 August 2008.

54 Rapporto Esercito 2008, p. 56.

55 Osservatorio permanente sulle forze armate, Percezione e attegiamento dell'opinione pubblica nei confronti delle Forze Armate, Eurispes, Rome, July 1997.

\section{Conclusions: Towards new forms of authoritarianism or militarism?}

In most if not all European or Western countries, there has been a trend in recent years of growing military involvement in domestic matters. However, even though this "inward turn" of the armed forces is a general development, the analysis of the cases of Germany and Italy also shows that there are considerable differences in the roles and tasks military forces have come to assume within the borders of the state. While the German Bundeswehr has been used for a significant and growing number of internal missions, and while there has been a lively debate around its potential domestic role, thus far its deployments on national territory have not gone beyond logistical and similar support activities. In Italy, by contrast, the armed forces have played a much more far-reaching internal role and have carried out several rather large-scale police-type operations on national territory in areas such as crime and immigration control or counter-terrorism.

These differences between the two countries can hardly be explained by one factor alone. Institutional, security-related as well as ideational reasons seem to be relevant. First, at the institutional level, it can be noted that the Italian internal security system is militarised to a considerably greater extent than is the case in Germany, because the Italian armed forces already have a strong presence in the internal security field through the Carabinieri. ${ }^{56}$ Second, in terms of security, Italy has arguably faced the more severe challenges to its domestic stability than any other European country, especially in the form of the country's various Mafia organisations. Finally, in ideational terms, German willingness to deploy the armed forces on national territory seems to be hampered by what can be called the country's post-WWII "strategic culture", of which the main elements include strong anti-militarism and a general reluctance to resort to military force; a factor that has been pointed out by several analyses. ${ }^{57}$ Just as German policy-makers, as a consequence of the country's historical experiences, have been much more hesitant than the governments of other European countries to deploy the armed forces outside the borders of the state in multilateral peace operations, in Germany the use of the military on the national territory is much more politically sensitive than elsewhere. This also suggests that although in all liberal democratic states the distinction between internal and external security, and between police and military functions, as a result of globalisation processes, is likely to be further eroded in the years to come, the concrete manifestation of this blurring might differ considerably from one country to the other.

Ultimately, the key question arising in this context is whether the increasing use of military forces on the national territory is just an unproblematic adaptation of states' security structures to a new security environment, or whether it also points towards new forms of authoritarianism and militarism, as is often claimed by critics. Given the relatively recent nature of

\footnotetext{
56 Even though the Carabinieri are primarily responsible for policing tasks, they are formally part of the Italian armed forces. In domestic military missions, they are typically deployed together with the (regular) army.

57 See, e.g., Kerry Longhurst, Germany and the Use of Force. The Evolution of German Security Policy, 1990-2003 (Manchester: Manchester University Press, 2004).
} 
this trend, it is of course too early to make a definite judgement. What seems clear, however, is that straightforward comparisons to the Nazi and Fascist experiences, which are sometimes made by critical voices, are at this point at least heavily exaggerated. ${ }^{58}$ While the Nazi and Fascist dictatorships used military and paramilitary forces with the explicitly political aim of fighting and destroying alleged internal "enemies", such as Jews or political opponents, current domestic deployments of the military can hardly be said to pursue such a clear political agenda, nor is their objective to "destroy" a specifically defined adversary. ${ }^{59}$ While these domestic military operations, of course, amount to a militarisation of internal matters and policing, in that they involve the use of military personnel and assets, there is at least so far no evidence that the troops deployed in these missions act with a "military mindset", for

58 See, e.g., Michael Head and Scott Mann, op.cit..

59 The argument made by Head and Mann that the domestic use of armed forces is a sign of increasing suppression of the disaffected classes by the dominant elites seems at this point at least overdrawn (Michael Head and Scott Mann, op.cit.). example by making excessive use of force. At least so far, it is noteworthy that critics of the domestic use of the armed forces usually take issue with this development mainly on grounds of principle - i.e. that such measures are counter to liberaldemocratic principles - rather than by pointing to actual abuses committed by military forces deployed in internal missions.

This, however, is not to say that there are not reasons for concern, as the internal use of military forces always bears at least the potential for abuse. While we might not (yet) be witnessing a fallback into authoritarianism and militarism, it cannot be excluded that current domestic deployments of the armed forces might only be the first steps towards much more far-reaching, and more politicised, involvement of military forces in internal matters. As such, the developments described above, of course, call for continuous and constant monitoring and assessment, not only in terms of their effectiveness with regard to domestic security provision but also with respect to their impact on basic human rights as well as the distribution of political power within the state.

\title{
Bundeswehr im Einsatz: Erweitertes Aufgabenspektrum und dessen Wahrnehmung im Spiegel der öffentlichen Meinung
}

\author{
Rüdiger Fiebig und Carsten Pietsch*
}

\begin{abstract}
This article presents findings from the annual public opinion survey on security and defence issues, conducted by the Bundeswehr Institute of Social Sciences. It focuses on the current and emerging spectrum of operations of the German armed forces engaging terrorist threats at home and abroad. Owing to its contributions to global military operations against terrorism, Germany has to re-evaluate its traditional military posture which is framed by the unique setting of the German constitution, due to its specific historic experience of 1933-1945. This article provides an overview of the institutional background as well as attitudes of the German population.
\end{abstract}

Keywords: Bundeswehr, Bevölkerungseinstellungen, Auslandseinsätze, Terrorismus, Innere Sicherheit, Öffentliche Meinung German armed forces, attitudes of the population, military operations abroad, terrorism, internal security, public opinion

\section{Einleitung ${ }^{1}$}

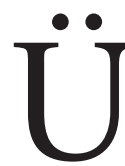

ber lange Zeit war die Sicherheits- und Verteidigungspolitik der Bundesrepublik Deutschland primär ausgerichtet auf den möglichen Verteidigungsfall,

* Rüdiger Fiebig ist wissenschaftlicher Mitarbeiter am Sozialwissenschaftlichen Institut der Bundeswehr, wo er als Projektleiter im Forschungsschwerpunkt Einstellungsforschung die jährliche Bevölkerungsumfrage zum sicherheitsund verteidigungspolitischen Meinungsbild der Deutschen sowie die Streitkräfteumfrage betreut. Carsten Pietsch ist wissenschaftlicher Mitarbeiter am Sozialwissenschaftlichen Institut der Bundeswehr im Forschungsschwerpunkt Sozialwissenschaftliche Begleitung der Auslandseinsätze der Bundeswehr. Er ist zudem Referent für Presse- und Öffentlichkeitsarbeit des Instituts. - Referierter Beitrag.

1 Die im vorliegenden Artikel vorgetragenen Ansichten und Meinungen sind ausschließlich diejenigen der Autoren und geben nicht notwendigerweise die Sicht oder die Auffassung des Bundesministeriums der Verteidigung wieder. Die Autoren danken den anonymen Gutachtern für wertvolle Hinweise und Kommentare. also die Verteidigung des Bundesgebiets gegen den Warschauer Pakt. Mit dem Zerfall der Sowjetunion ist der deutlich sichtbare Gegner im Osten wie auch die bis dahin vorrangige, „klassische“ Aufgabe der Bundeswehr entfallen.

Nach der Wiedererlangung der vollen Souveränität Deutschlands und losgelöst aus der Stasis der Blockkonfrontation ergab sich für die Bundeswehr auch eine Erweiterung ihres Aufgabenspektrums, das im Rahmen der Auslandseinsätze seit den 1990er Jahren von weltweiten humanitären Hilfseinsätzen bis hin zur Aufstandsbekämpfung reichte, und in denen zum ersten Mal seit Ende des Zweiten Weltkriegs deutsche Soldaten in Gefechte verwickelt waren. Das 21. Jahrhundert brachte für die Bundesrepublik neue sicherheitspolitische Herausforderungen wie den internationalen Terrorismus, der gegenüber klassischen militärischen Bedrohungen nicht durch Landes- 